\title{
SUSTAINABLE NAVIGATION BY THE DANUBE - LAW REGULATIONS, PROBLEMS AND PROPOSALS
}

\author{
Milan M. Kresojević* \\ University of Defense in Belgrade, Military Academy \\ Saša T. Bakrač \\ Military Geographical Institute, Belgrade \\ Aca J. Ranđelović, Dušan N. Stošić \\ University of Defense in Belgrade, Military Academy
} \begin{abstract}
he Danube navigation in the territory of the Republic of Serbia has a
negative impact on the environment, mostly in the form of pollution emitted from ships. The aim of the paper is to point out the existence and need for implementation of legislation regulating the navigation of passenger and cargo ships on the Danube. It is considered that the consistent implementation of the existing regulations and compliance control will give significant results in improving the state of the river environment and its wider surroundings. The paper aims to raise the awareness of potential users about the importance and potential of sustainable navigation. Bearing in mind the international importance of the Danube Basin and implementation of the development strategy for this river within the European Union countries, it is necessary to identify and actively participate in the implementation of the sustainable navigation concept. In this sense, it is considered that the cooperation with the Danube Basin countries is necessary. Thus, in the forthcoming period, it would be important to harmonize regulations and technical requirements for vessels, control mechanisms, waste disposal options and the overall monitoring.
\end{abstract}

Key Words: Danube River, legal regulations, sustainable navigation, pollution, cross-border cooperation

\section{Introduction}

The Danube River, with the total length of $2,860 \mathrm{~km}$, is suitable for sailing from Ulm (Germany) to the Black Sea. The whole stream is navigable through the Republic of Serbia, from Bezdan to Prahov, in the length of $588 \mathrm{~km}$. The section between Ulm and Kelheim (Germany) is navigable only for smaller ships of up to 250 gross tonnage. The

\footnotetext{
*milan.kresojevic@va.mod.gov.rs

**sasa.bakrac@vs.rs
} 
International Danube waterway, which extends over 2,414km between Kelheim and Sulina (Romania) is the link between the North Sea and the Black Sea, across the Rhine Main - Danube Canal and represents the Pan - European Transport Corridor VII (Petrović, 2015).

Due to the development of the economy and the general economic importance, waterway transport has become an unavoidable trend in Europe in recent years and therefore in the Republic of Serbia, through which even three international navigable rivers flow (Radojević, 2012).

The Danube Basin, which belongs to the Republic of Serbia, has around 390 protected areas of special national and international importance (The Government of the Republic of Serbia, 2008). Along the riverbank of the Danube, some of the most beautiful European cities have been built, as well as a lot of resorts and national parks, and river traffic has significantly developed. Unfortunately, in addition to these positive effects, rapid spatial development has negative impacts on the environment manifested in the form of pollution of the same (Bakrač, 2007).

In order to gain a clearer picture of the importance of the inland navigation development (hereinafter: IND), the countries with which the Republic of Serbia is linked by the Danube river cannot be ignored, as well as the fact that the Danube is the second largest European river. The European canal and river network makes up a waterway in the total length of about $30,000 \mathrm{~km}$. The waterways connect industrial centers and regions. In addition to the Rhine, the Danube and the Rhine-Main-Danube canal, there is a dispersed network of small tributaries and canals connecting smaller cities with industrial centers.

River ports are mostly located in the centers of major European cities and they are suitable for intermodal transport. For the transport of goods of different characteristics the most convenient is IND because of the high flexibility in business. The main advantage of IND traffic is a lower price in comparison to other modes of transport. This is achieved by combining the speed of the river flow and the size of the ships. In addition, the advantage of this transport is its reliability, as there is no problem of congestion and bottlenecks, which occurs in other modes of transport. Nevertheless, there is the risk of incidents, which could have a negative effect on the environment (Bakrač, 2007). The risk of incidents depends largely on the load of the waterway, the state of the waterway (water depth, river speed, conditions of the atmosphere, marking...), the navigation speed, training and reliability of the crew, the technical condition of the ship, as well as the presence of navigational devices on board, etc. Most rivers and canals are navigable 24 hours a day, and this type of traffic causes the least number of accidents (Zarić - Vujičić, 2012).

Despite the advantages the IND transport has not yet been sufficiently utilized. Freight inland navigation has a 7\% share of the total transport (Đurđev, 2012). One container ship can load 200t/h to $400 \mathrm{t} / \mathrm{h}$, which is a container of 6 meters every two to three minutes. If the ship works with two to three cranes, it can load or unload 20,000 to 24,000 gross tones cargo per day (Radojević, 2011). In order to show the ratio of cargo that ships can transfer, in relation to other types of traffic, it is stated that one ship can carry cargo of 93 wagons and 173 trucks. There are about 1100 boats on the Danube, which is almost 10 times less than on the Rhine (ICPDR, 2018). 
Inland waterway navigation is not with a predefined risk for the environment (Bakrač, 2012). However, sailing has an impact on the environment, which is manifested through different pollution patterns. The sustainable navigation and sustainable management issue has become more and more relevant and gets problematic in consideration and resolution.

\section{Sustainable Navigation - Legislation The Development Strategy of the Danube Region}

Taking into account the plans for the development of inland navigation and the amount of planned budget (Dimitrijević, 2015), it is necessary to actively engage and learn more about how to protect the environment. The European Union has adopted the development strategy for the Danube Basin countries by 2025. On $24^{\text {th }}$ June 2011 , the Council of the EU made a conclusion by the common comprehensive strategy (hereinafter: Strategy) approved by the Council of the European Union (the European Movement in Serbia), inviting all the actors to engage in the implementation of the Strategy. This is why the process of adoption of the Strategy has been formally completed (RS Government, 2014). The significance of the Strategy for the EU countries is also considered from a political point of view in terms of contributing to the significant improvement in the relationship between states (Martonji, 2011).

The Danube Strategy is based on the four pillars: connecting the Danube Region, protecting the environment in the Danube Region, building prosperity in the Danube Region and strengthening the Danube Region (Dimitrijević, 2015). Active participation and contribution of Serbia lies in the fact that it is one of the coordinators for the two areas of the Strategy: Science and Transport (Zarić - Vujičić, 2012).

Considering the issue of IND traffic in the past years, the emphasis is on giving increasing attention to this type of traffic. Almost every major international document or development strategy indicates the advantage and mechanisms of the river transport development, as a component of modular transport. The structure of sustainable development can be formally mathematically represented by the formula:

$$
\mathrm{U}=\mathrm{P} * \mathrm{Pur}^{*} \mathrm{~T}
$$

where the total impact $(U)$ is directly proportional to the product of the population $(P)$, the resource management consumption (Pur) and technology (T) (Veljković, 2012). The acquired formula can be redefined and applied to the total pollution emitted by IND vessels. Thus, new pollution from the vessel formula can be defined:

$$
\mathrm{U}=\mathrm{PI}{ }^{*} \mathrm{Pur}^{*} \mathrm{~T}
$$

(PI) represents the total reliability of the waterway by vessels, (Pur) vessel consumption (propulsion fuel, lubricants and other oils on board), the established sustainable navigation management and $(\mathrm{T})$ technology and technique used on the vessel. 
Sustainable development is regulated by European Union regulations, international agreements and national norms. International cooperation, harmonization of regulations and practice is the basis of the creation of sustainable navigation of the IND, (Horvat, 2014).

Considering the fact that in all the countries located on and within the waterways the essential issues for the acceptance and disposal of waste are not solved, international cooperation is necessary and purposeful. International cooperation, especially in the field of environmental protection, due to the synergistic approach to problem solving, is best carried out and implemented through various projects. Thus, the project WANDA (Waste Management for Inland Navigation on the Danube) was completed in 2012. The main objective of the project was to create solutions for the disposal of waste from vessels on the Danube River. After completion of the above mentioned, the project continued in the same direction together with the CO-WANDA project (Convention for Waste Management for Inland Navigation on the Danube), which aimed to develop an international convention to regulate waste management from vessels along the Danube River (Plovput, 2012).

During the project the Directorate Plovput equipped the inland navigation vessels with transponders from the "River Information System" (RIS), which represents the form of international cooperation. The RIS operates successfully in the territory of the Republic of Serbia and it is controlled by the Directorate Plovput, based in Belgrade. In the further development and implementation of the RIS, the plan is to improve the data that is necessary for the development of sustainable inland waterway transport.

\section{International regulations and water protection in the European Union}

In the case of international acts, there are different acts that are specific for the Danube River or the Danube countries, documents applied to the European and/or international level, as well as binding documents of the European Union countries (Horvat, 2014).

In the European Union, the European Parliament Directive (EU - Water Framework Directive of European Parliament and of the Council 2000/60/EC - Establishing a Framework for Community Action in the Field of Water Policy /ODV/) is in force (Jović, 2016). This directive specifies the objectives of water protection and measures, procedures and actions which imply it. "The Directive prevails by the regulations of the European Union in the water sector, primarily by setting goals in the field of environmental protection and by prescribing the process of water management planning that includes: monitoring, evaluation and analysis of pressures and impacts; preparation and implementation of sixyear river basin management plans designed to achieve environmental objectives" (Jović, 2016, page 199). In addition to this Directive, the following are in force:

- Directive 2000/60/EC of the European Parliament and of the Council of $23^{\text {rd }}$ October 2000;

- Directive 91/271/EEC (Council Directive 91/271/EEC of $21^{\text {st }}$ May 1991 concerning urban wastewater treatment);

- Directive 2007/60/EC (Directive 2007/60/EC of the European Parliament and of the Council of $23^{\text {rd }}$ October 2007 on the assessment and management of flood risks Text with EEA relevance); 
- Directive 98/83/EC (Council Directive 98/83/EC of 3rd November 1998 on the quality of water intended for human consumption);

- Directive 2006/7/EC (Directive 2006/7/EC of the European Parliament and of the Council of 15th February 2006, concerning the management of bathing water quality and repealing Directive 76/160/EEC);

- Directive 91/676/EEC (Council Directive 91/676/EEC of 12th December 1991 concerning the protection of waters against pollution caused by nitrates from agricultural sources);

- Directive 76/464/EEC (Council Directive 76/464/EEC of 4th May 1976 on pollution, caused by certain dangerous substances discharged into the aquatic environment of the Community);

- Directive 80/68/EEC (Council Directive 80/68/EEC of 17th December 1979 on the protection of groundwater against pollution caused by certain dangerous substances);

- Directive 2006/118/EC (Directive 2006/118/EC of the European Parliament and of the Council of 12th December 2006 on the protection of groundwater against pollution and deterioration);

- Directive 96/61/EC (Council Directive 96/61/EC of 24th September 1996 concerning integrated pollution prevention and control) (Jović, 2016).

In addition to legal regulations related to the sustainable development of navigation on inland waterways, the competent body of the European Union has issued the waste catalog, where the generated waste is recorded, as well as the types of waste that occur on vessels.

One of the most important documents on the sustainable development of navigation is the "Joint Statement on the Guiding Principles for the Development of Inland Navigation and Environmental Protection in the Danube River Basin" (ICPDR, 2007). The aim of this Joint Statement is to provide guidance to all those dealing with IND navigation issues and environmental sustainability. In particular, it refers to institutions and organizations involved in water management, and its work to develop plans, programs and projects in the field of ecology and navigation. The creation process of the Joint Statement has been initiated by the International Commission for the Protection of the Danube River (ICPDR), the Danube Commission (DC) and the International Commission for the Sava River Basin (ISRBC).

One of the most important international conventions is the "Convention on the Navigation System on the Danube from 1948", the so-called Belgrade Convention (Danube Commission, 1948). The Belgrade Convention signed in Belgrade on August $18^{\text {th }} 1948$ is an international legal instrument regulating navigation on the Danube River. The Convention allows free navigation on the Danube, in accordance with the interests and sovereign rights of the contracting parties to the convention, aiming at strengthening the economic and cultural relations between them and with other nations. According to the Convention, 11 member states (Germany, Slovakia, Austria, Croatia, Hungary, Bulgaria, Moldova, Romania, Russia and Ukraine) are obliged to maintain their part of the Danube in a navigable condition for river vessels and at the appropriate parts for maritime navigation. The members have undertaken to carry out the works necessary for maintaining and improving the conditions of navigation, as well as not to hinder or impede navigation on the Danube waterways. "Convention on Cooperation on the Protection and Sustainable Use of the Danube River" (Jović, 2016) was signed in Sofia on June $29^{\text {th }} 1994$. The main objective of the Danube River Protection Convention (DRPC) is to ensure that sur- 
face and ground waters in the Danube River Basin are managed and used sustainably and fairly, which includes:

- the preservation, improvement and rational use of surface and ground water;

- preventive measures to control the risk of accidents involving floods, ice or dangerous substances;

- measures to reduce pollution entry that comes from the basin of the Danube River to the Black Sea

One should not skip the "Convention on the collection, disposal and acceptance of waste generated during navigation on the Rhine and inland waterways" (Jović, 2016). The Convention is prescribed for the Rhine River, as well as for other waterways in Germany, where it is adhered. The "polluter pays" principle is governed by this Convention in such a way that the fee is paid when fuel is charged through universal tax on regulated parts. The "polluter pays" principle and "precautionary" principle represent basic measures for the protection of the Danube and its Basin, in order to establish the sustainable exploitation of the Danube River.

"The European Agreement on the Transport of Dangerous Goods by Inland Waterways - AND", which contributes to meaningful sustainable development of dangerous goods and prevention of stains arising from accidents during the transport of the mentioned cargo (Trifković, 2013). Special attention is paid to the legislation on the transport of dangerous goods. In 1954 the United Nations Economic and Social Council ECOSOC founded the Committee of Experts on the transport of dangerous goods by various modes of transport. The Committee's task was to define standard rules for safe transport of dangerous goods on whose basis the member states will harmonize their own national regulations. This is how the "Recommendation of the Safe Transport of Dangerous Goods" was created (the so-called "Orange Book") (Trifković, 2013).

The transport of dangerous goods in the international traffic is regulated by the following documents:

ADR (Accord européen relatif au transport international des marchandises dangereuses par route);

RID (International Carriage of Dangerous Goods by Rail);

ICAO-TI (International Civil Aviation Organisation-Technical Instructions);

IMDG Code (International Maritime Dangerous Goods).

The International Maritime Organization (IMO) is further defined by the regulations on the protection of life at sea (International Convention for the Safety of Life at Sea SOLAS), which has prescribed rules on the transport of the dangerous goods in the chapter VII. This chapter contains the following parts:

A (Transport of dangerous packed goods, IMDG Code);

A1 (Transport of solid dangerous goods in ship warehouses);

B (Construction and equipping of ships and transport of dangerous chemicals in liquid state, IBC Code);

C (Construction and equipping of ships for the transport of liquefied gases, IGC Code);

D (Transport of Nuclear Fuel and Radioactive Waste, INF Code) (Trifković, 2017).

In addition, our country has followed the valid regulations in the field of sustainable navigation development, primarily to comply with the EU legislation. That is how " rules on preventing pollution and inland water caused by navigation" is prescribed (The Government of the Republic of Serbia, 2017). 
This regulation prescribes the obligations and measures taken by the commander of the vessel in order to prevent pollution, handling oily and greasy substances, waste oils and fuel residues, measures related to collection, sorting and marking the municipal waste and other special waste, requirements that have to be met by ships, floating objects and receiving stations in order to prevent pollution, the way of cleaning the load compartment, i.e. the tanks, the way of discharging the cargo residues and the requirements for the residue vessels, the wastewater treatment on the passenger ship, the border and control values at the outlet of the wastewater treatment plant on the passenger ship, the types of technical resources required to respond to spills, the way in which the authorities in charge of responding to pollution caused by navigation and mandatory elements of technical and operational plans to prevent pollution, that is reducing and mitigating the consequences of the generated pollution (The Government of the Republic of Serbia, 2017, Article 1).

\section{Problems and suggestions for improving the situation}

Analyzing the situation on the Danube waterway through our country particularly if we look at the conclusions that were adopted in 1999 by the "UN ECE Inland Transport Committee, Trans/SC.3/150", (Economic Commission for Europe (ECE), 2007), we can identify the key problems of establishing sustainable navigation:

- There are no specialized vessels for collecting solid and liquid waste from the vessels.

- The ports do not have regulated waste management from ships, or do not possess a certificate or developed procedures, as well as technical capabilities.

- There are no services for collecting waste materials from the vessels.

- Planned and synchronized waste collection occurs only in accidents and incidents (Presburger - Ulniković, 2011).

If we compare the conclusions made by the experts engaged in making a decision to establish the sustainable development along the Danube River waterway by the UN ECE, and the real situation of our part of the waterway, one can see the scope of the results achieved during the accession negotiations period.

The experts have made the following conclusions:

- All pollutants should be collected on board.

- When entering the ship, they should be delivered to further processing to receiving stations on land.

- Receiving stations should be equipped with the necessary equipment for collecting and further processing the waste, and to be at the required distance from each other.

- In order to minimize environmental impact, all shipping companies should use the latest technologies on ships to minimize the detrimental effect on the environment.

- Each country should adapt its ports to be the most suitable for the landing and disposal of waste.

- The "polluter pays" principle should be applied, instead of direct payment, so that ship owners do not save the waste, which directly encourage them to discharge their waste into water courses (Economic Commission for Europe (ECE), 2007). 


\section{Conclusion}

Sustainable navigation, as defined in this paper, would greatly popularize this type of transport. This would have a positive effect on the overall economic situation in our country. Vessels (boats), despite numerous advantages over the other modes of transport, especially the freight traffic (cargo), are serious contaminants on the Danube River. Unless sustainable navigation is established, the situation on the Danube River, as well as on our other rivers, could further aggravate.

The situation could be controlled and improved by implementation of good governance measures, properly prescribed procedures and application of vessels procedures. One of the first steps is to establish an eco-station along the waterway and to equip the port with the equipment for establishing sustainable navigation.

The overall conclusion is that the Republic of Serbia has much more room for infrastructure and other investments in the establishment of sustainable navigation on its part of the Danube River waterway.

It is believed that there is the risk of pollution of the Danube River. The assessment of this risk should be carried out by scientific methods, which would determine the overall state of the river environment and its wider surroundings. 